\title{
A new quantitative classification of ecological types in the bromeliad genus Tillandsia (Bromeliaceae) based on trichomes
}

\author{
Mosti Stefano, Alessio Papini \& Luigi Brighigna* \\ Dipartimento di Biologia Vegetale, Università degli Studi di Firenze, via La Pira, 4-50121 Firenze, Italia. * Phone: \\ 0039-055-2757393. Fax: 0039-055-2757398; luibrig@unifi.it
}

Received 10-I-2006. Corrected 30-III-2007. Accepted 22-VIII-2007.

\begin{abstract}
Using collection specimens, we measured the density and wing area of trichomes in 37 species of the bromeliad genus Tillandsia, specifically the abaxial proximal, abaxial distal, adaxial proximal and adaxial distal parts of the leaf. The product of the trichome "wing" area by the number of trichomes (means) produced a pure number $(\mathrm{T})$ that was correlated to ecological features. The correlation was positive with respect to arid environments (xeric Tillands) and negative with respect to humid environments (mesic Tillands). Bulbous, and particularly myrmecophytic species and species with tanks, represented particular categories. Other intermediate types were identified based on the T number, totalling five ecological types. In comparison with other systems of ecological typification for Tillands and other Bromeliaceae, the present system offers measurable data whose analysis is reproducible. Rev. Biol. Trop. 56 (1): 191-203. Epub 2008 March 31.
\end{abstract}

Key words: Bromeliaceae, ecological types, Tillandsia, trichome.

The absorbing trichomes, also called 'trichopumps' by the German botanist Mez (1904), are the keystones of the epiphytism in Tillandsia (Bromeliaceae). The trichomes of this neotropical monocots are nail-shaped multicellular structures, done of a horizontal shield developing over the leaf surface and a vertical axis penetrating into the mesophyll (Billings 1904, Mez 1904, Benzing 1980, Rauh 1981). Studies on the morphology and evolution of Tillandsia trichomes have been written by Strehl and Winkler (1982) and Winkler $(1980,1986)$ who also indicated a relationship of trichomes and stomata frequency to the subgenera of Tillandsia (Winkler 1990). Water coming in contact with the leaves is absorbed by the peripheral cells of the shield, passes to the central ones, flows down through the underlying axis cells and is distributed to the internal tissues along a set course that can be compared (under the functional of view) to that followed by solutions in the roots of terrestrial plants
(Brighigna et al. 1988). When the plant is dry the trichomes maintain their mobile parts (the wing) up, giving the leaf an apparent grey color. When the plant is wet, the wings descend, adhering to the leaf surface that so recovers its bright green color. The adactive plasticity of Tillands allows them to develop in very different habitats, like deserts (Sonora, Pachacamac), rain forests (Veracruz, Amazon Basin) and mesic woods of the plateaus (Puebla, Potosi) and to create symbiotic relationships to small invertebrates. This flexibility suggested the search for more ecological types at the internal of the genus Tillandsia (Mez 1935, Pittendrigh 1948, Gilmartin 1983, Benzing and Renfrow 1971, Benzing et al. 1979). Mez defined the 'atmospheric' Tillands and Pittendrigh the 'tank with absorbing trichomes' and the 'atmospheric with absorbing trichomes', while Benzing divided Pittendrigh's second type into 'true atmospherics' and 'myrmecophytic atmospherics'. Gilmartin (1983) separated the representatives 
of the genus in 'mesic', 'semimesic' and 'xeric'. Benzing (2000) proposed five ecophysiological types for Bromeliaceae, two of which applied to genus Tillandsia: type IV (with well developed phytotelma and absorbing trichomes on the leaf base) and type V (no phytotelma, often neotenic and miniaturized and absorbing trichomes on the whole surface). All these definitions followed the necessity of giving more importance to one feature or the other, but we think that the true discriminating factor, from an ecological point of view, is the absorbing trichome with their functional roles.

Precisely, besides the absorption of nutrients, Tillandsia trichomes perform also other not secondary functions. These functions are:

a. The capability of collecting atmospheric water (rain, fog, frost) and to distribute it on the leaf surface, contemporaneously reducing the loss caused by evaporation (Tomlinson 1969, Benzing 1979).

b. The protection against sun radiation by the increase in reflecting surface (Benzing 1980).

c. The collection and the mechanical blocking of mineral nutrients and organic particles on leaves that are then transported inside the leaf.

d. Caption and mechanical retaining of organic particles and mineral nutrients on leaves and later entering inside (Tukey 1970, Benzing 1980, Brighigna 1991).

e. The hosting of degrading phyllospheric microflora (bacteria, fungi, yeasts) and nitrogen-fixing cyanobacteria.

The presence of these last assumes an important ecological meaning for these epiphytic plants (Favilli et al. 1975, Brighigna et al. 1992). Hence we are convinced that to define ecological types in Tillandsia it is not possible to neglect the different weight in different species in all the above mentioned functions. The effectiveness of each of these function is quantifiable in relation to the increase of the interchange surface plant-environment due to the presence of the trichomes.
This increase is expressed by the wing dimension and by the number of trichomes on the leaf surface. These parameters can vary from species to species and are able to influence the environment 'choice'. In the present work our aim was to analyse from this point of view a significant number of Tillandsia species in order to produce a scale of numerical values, expressing the increase in surface in the single species. The final aim was to segregate, at the internal of the scale, coherent discrete intervals to be used to define objectively original ecological types.

\section{MATERIALS AND METHODS}

For trichomes counting and to calculate the wing area we chose the following species:

- T. heterophylla E. Morren, T. latifolia Meyen var. latifolia, T. remota Wittm. and T. tectorum Morren of subgenus Allardtia (A. Dietrich) Baker;

- T. albertiana F. Vervoost of subgenus Anoplophytum (Beer) Griseb;

- T. anceps Lodd., T. crocata (Morren) Baker, T. cyanea Linden var. cyanea, T. duratii Vis. var. duratii, T. paleacea Presl, T. purpurea Ruiz \& Pavon of subgenus Phytarrhiza (Visiani) Baker;

- $\quad$ T. recurvata (L.) L. and T. usneoides (L.) L. of subgenus Diaphoranthema (Beer) Baker;

- T. achyrostachis Morren, T. albida Mez \& Purp., T. balbisiana Schult., T. bourgaei Baker, T. bulbosa Hook., T. califani Rauh, T. caput-medusae Morren, T. circinnatoides Matuda, T. dasyliriifolia Baker, T. fasciculata SW., T. flabellata Baker, T. foliosa Martens et Galeotti, T. ionantha Planch., T. juncea (Ruiz \& Pav.) Poir., T. karwinskyana Schult. fil., T. prodigiosa (Lem.) Baker, T. punctulata Schlecht. \& Cham., T. schiedeana Steud., T. seleriana Mez, T. tricolor Sclecht \& Cham., T. violacea (Beer) Baker and T. xerographica Rohw. of subgenus Tillandsia L.; 
- T. grandis Schlect. of subgenus Pseudalcantarea Mez.

More specimens of the list above have been collected by the authors during two scientific expeditions to Costa Rica and to Central Mexico, respectively in 1993 and 1997. Other specimens have been chosen among those belonging to the collection of the Botanical Garden of Florence, collected by one of the authors during previous expeditions. Also some herbarium samples from the Herbarium Centrale Italicum (FI) and the Tropical Herbarium of Florence (FT) have been used.

The chosen species have been considered exhaustive to consider all morphological and ecological adaptations of the genus. In the list some species with "tank" morphology are present (e. i. T. heterophylla, T. grandis). Other species are defined as strictly "atmospheric" (as $T$. usneoides, T. recurvata, $T$. crocata); other species are bulbous myrmecophytic (as $T$. bulbosa, T. caput-medusae); species with succulent leaves (as T. albertiana). The remaining species cannot be defined precisely after one of this morpho-ecological definitions, hence they deserved an unbiased analysis.

Also the habitats of these species are very variable. Some taxa live in humid tropical forests (for instance T. cyanea, T. heterophylla, $T$. foliosa), other in desert or subdesert environment (as T. recurvata, T. albida, T. califani), other in coastal areas (T. purpurea, T. latifolia, T. paleacea), other colonizes habitats with intermediate features (T. fasciculata, T. bulbo$s a$ ). Finally some species are almost ubiquitous (T. schiedeana, T. usneoides). Also from the point of view of the ecological adaptations, all aspects are present in our list. We considered: strictly epiphytic species, epilithic species ( $T$. purpurea, T. albertiana, T. latifolia) and stoloniferous species forming colonies (for instance T. usneoides, T. recurvata). Other species that show intermediate situations, such as T. albida or T. circinnatoides, able to live both as epiphytes and on the ground, were also included.

From the point of view of the geographical distribution we considered taxa from northern or central America (USA, Mexico, Costa Rica, Guatemala, Honduras, El Salvador, Trinidad) and taxa coming from South America (Venezuela, Colombia, Chile, Peru, Ecuador, Brazil, Bolivia, Argentina).

To evaluate the frequence of trichomes in the different species we took square fragments with sides of about $0.5 \mathrm{~cm}$ in different zones of the leaf in at least three specimens (if possible from different populations) for each taxon. To help the detachment (done manually) of the cuticle film from the epidermal tissue including the external part of the trichomes, we put the fragments in a water solution with $1 \%-2 \% \mathrm{NaOH}$ (depending on the species) for 48-72 hours. This method was an adaptation from Foster (1950). It resulted useful to obtain cuticular fragments free of epidermal and parenchyma remnants that would reduce the transparency of the sample (Fig. 1). After the detachment of the cuticle fragments were washed in distilled water, stained with Safranine (1\%, in water solution) and mounted on a slide (Foster 1950).

The count of trichomes was done with a binocular Zeiss 4750529901 microscope with a micrometrical grid attached to the objective lens.

For each species we calculated mean and standard deviation of number of trichomes/ $\mathrm{mm}^{2}$ in the four (when possible) chosen leaf zones (proximal adaxial $=\mathrm{AD}$ pro.; proximal abaxial $=\mathrm{AB}$ pro.; distal adaxial $=\mathrm{AD}$ dis.; distal abaxial $=A B$ dis.). From these values we obtained the general mean of trichomes/ $\mathrm{mm}^{2}$ typical of a single species on the basis of 50-100 counts for each species, taking into account both the number of specimens and the different zones of the leaf.

Trichome shield area calculation: to aid the total detachment of the epidermis from the trichome shields we treated the fragments with a $10 \% \mathrm{NaOH}$ water solution for about 48 hours. $\mathrm{NaOH}$ concentration and the time of reaction were the most appropriate for all the investigated species. The trichome shields were centrifugated and stained for 1 hour in $1 \%$ Safranine and $0.03 \%$ Toluidine Blue in $0.1 \mathrm{M}$ Phosphate buffer at $\mathrm{pH} 7$. 


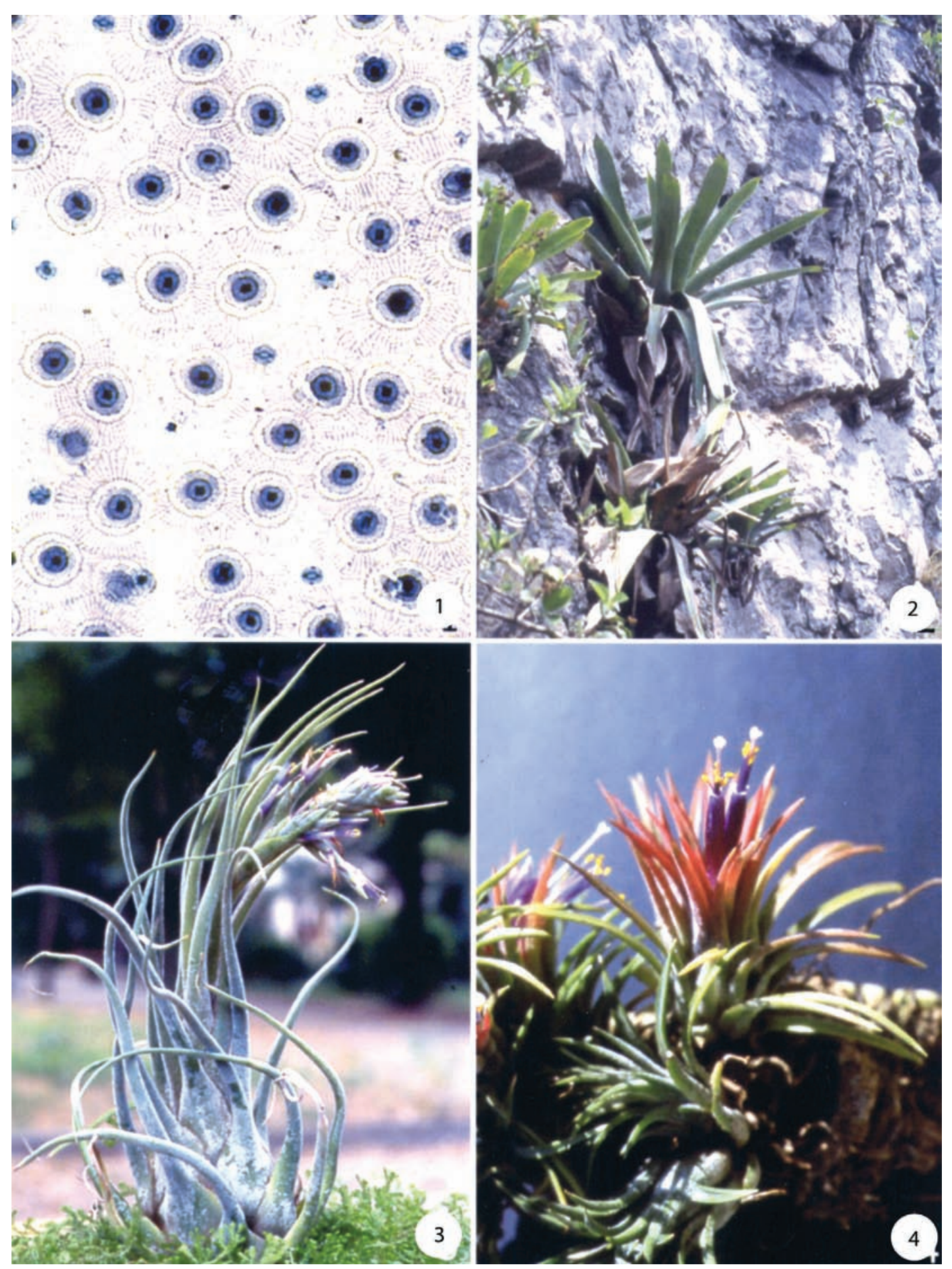

Fig. 1. A cuticular portion at light microscope. Stained with Safranine. Fig. 2. Tillandsia grandis: minimally expanded type. Fig. 3. Tillandsia seleriana: poorly expanded type. Fig. 4. Tillandsia ionantha: averagely expanded type. 

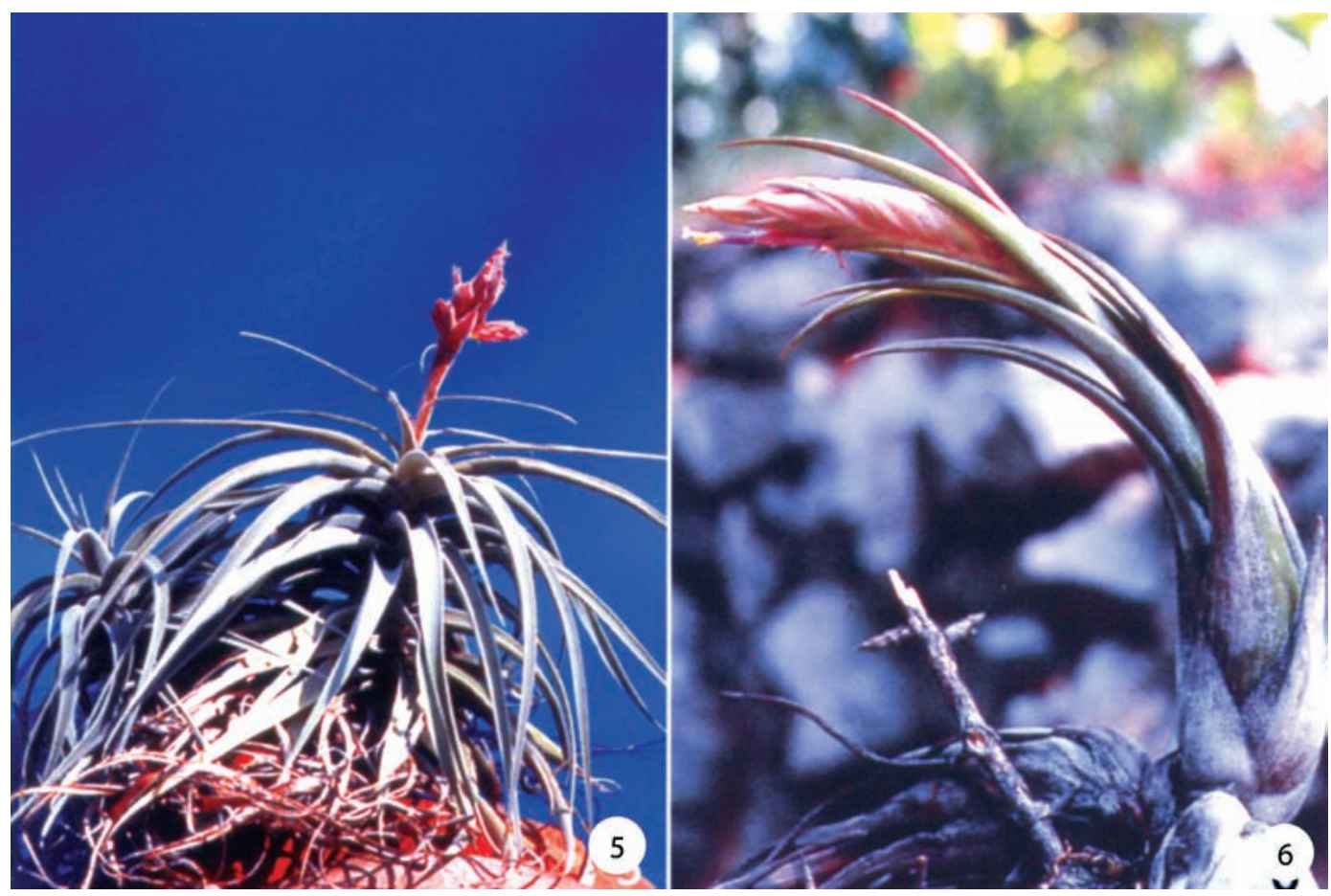

Fig. 5. Tillandsia purpurea: highly expanded type. Fig. 6. Tillandsia circinnatoides: utmostly expanded type.

After the staining we centrifugated again the material and we mounted it on slides. The observations were done with a Leitz Orthoplan light microscope. During the observations, for each species, we took about 40 photographs of trichomes, randomly chosen. Photographs were taken with an Orthomat Leitz camera. Afterwards we developed prints from negatives with final magnification of $100,8 \mathrm{x}$ or $252 \mathrm{x}$.

We calculated the mean area of the trichome wing in each species considering 40 samples with a Digital Planimeter KP-80 Placam Koizumi. We excluded the central disc of the trichome that does not indicate any increase in epidermis surface. These measurements were in $\mathrm{mm}^{2}$. The value, together with the trichome frequency, was used to calculate the amount of "leaf expansion" typical of a given species.

\section{RESULTS}

Results appear in three tables, respectively, the area of the trichome wing (Table 1) and the number of trichomes $/ \mathrm{mm}^{2}$ (Table 2) per zone on the leaves in each of the 37 species. Table 3 reports the values of "leaf expansion" $(\mathrm{T})$ typical of each single species as resulted from the combination of the factors reported in the first two tables. On the whole we can say that:

$$
\mathrm{T}=(\mathrm{a} \cdot \mathrm{n})
$$

where $\mathrm{a}$ is the mean area in $\mathrm{mm}^{2}$ of the trichome in each species, $\mathrm{n}$ is the mean number of trichomes $/ \mathrm{mm}^{2}$.

Five ecological types are distinguished (Figs. 1-6). Fig. 7 presents the measurement variation from Table 3. 
TABLE 1

Trichome wing areas

\begin{tabular}{|c|c|c|c|c|c|}
\hline Species & ADPRO & ADDIS & ABPRO & ABDIS & Mean \\
\hline T. achyrostachys & 0.026 & 0.026 & 0.026 & 0.026 & 0.026 \\
\hline T. albertiana & 0.030 & 0.022 & 0.040 & 0.020 & 0.025 \\
\hline T. albida & 0.061 & 0.061 & 0.070 & 0.070 & 0.066 \\
\hline T. anceps & 0.024 & 0.024 & 0.034 & 0.033 & 0.029 \\
\hline T. balbisiana & 0.057 & 0.057 & 0.039 & 0.039 & 0.048 \\
\hline T. bourgaei & 0.059 & 0.098 & 0.059 & 0.103 & 0.081 \\
\hline T. bulbosa & 0.050 & 0.099 & 0.058 & 0.029 & 0.040 \\
\hline T. califani & 0.062 & 0.050 & 0.106 & 0.034 & 0.048 \\
\hline T. caput-medusae & 0.127 & 0.054 & 0.098 & 0.116 & 0.122 \\
\hline T. circinnatoides & 0.112 & 0.112 & 0.172 & 0.172 & 0.142 \\
\hline T. crocata & 0.044 & 0.049 & 0.047 & 0.049 & 0.047 \\
\hline T. cyanea & 0.016 & 0.016 & 0.015 & 0.015 & 0.016 \\
\hline T. dasyliriifolia & 0.042 & 0.035 & 0.065 & 0.045 & 0.044 \\
\hline T. duratii & 0.109 & 0.100 & 0.081 & 0.108 & 0.109 \\
\hline T. fasciculata & 0.047 & 0.047 & 0.080 & 0.070 & 0.059 \\
\hline T. flabellata & 0.012 & 0.012 & 0.025 & 0.025 & 0.019 \\
\hline T. foliosa & 0.011 & 0.014 & 0.016 & 0.016 & 0.014 \\
\hline T. grandis & 0.017 & 0.010 & 0.030 & 0.030 & 0.024 \\
\hline T. grandis (juv.) & 0.080 & 0.080 & 0.080 & 0.085 & 0.083 \\
\hline T. heterophylla & 0.004 & 0.004 & 0.004 & 0.004 & 0.004 \\
\hline T. ionantha & 0.063 & 0.063 & 0.118 & 0.118 & 0.091 \\
\hline T. juncea & 0.079 & 0.072 & 0.044 & 0.072 & 0.076 \\
\hline T. karwinschyana & 0.088 & 0.088 & 0.203 & 0.202 & 0.145 \\
\hline T. latifolia & 0.066 & 0.066 & 0.066 & 0.066 & 0.066 \\
\hline T. paleacea & 0.077 & 0.110 & 0.077 & 0.110 & 0.094 \\
\hline T. prodigiosa & 0.033 & 0.033 & 0.046 & 0.046 & 0.040 \\
\hline T. punctulata & 0.028 & 0.016 & 0.029 & 0.034 & 0.031 \\
\hline T. purpurea & 0.118 & 0.127 & 0.148 & 0.127 & 0.123 \\
\hline T. recurvata & 0.112 & 0.131 & 0.112 & 0.131 & 0.122 \\
\hline T. remota & 0.040 & 0.044 & 0.040 & 0.044 & 0.042 \\
\hline T. schiedeana & 0.097 & 0.097 & 0.080 & 0.080 & 0.089 \\
\hline T. seleriana & 0.062 & 0.066 & 0.105 & 0.105 & 0.084 \\
\hline T. tectorum & 0.237 & 0.237 & 0.237 & 0.237 & 0.237 \\
\hline T. tricolor & 0.035 & 0.016 & 0.028 & 0.031 & 0.033 \\
\hline T. usneoides & 0.096 & 0.096 & 0.096 & 0.096 & 0.096 \\
\hline T. violacea & 0.019 & 0.019 & 0.048 & 0.048 & 0.034 \\
\hline T. xerographica & 0.039 & 0.039 & 0.044 & 0.044 & 0.042 \\
\hline
\end{tabular}

ADPRO $=$ Adaxial Proximal; ADDIS $=$ Adaxial Distal; ABPRO $=$ Abaxial Proximal; ABDIS $=$ Abaxial Distal. 
TABLE 2

Number of trichomes $/ \mathrm{mm}^{2}$

\begin{tabular}{|c|c|c|c|c|c|}
\hline Species & ADPRO & ADDIS & ABPRO & ABDIS & Mean \\
\hline T. achyrostachys & $23.9 \pm 1.3$ & $28.8 \pm 2.2$ & $32.3 \pm 5.5$ & $19.8 \pm 1.2$ & $26.2 \pm 2.5$ \\
\hline T. albertiana & $28.5 \pm 1.8$ & $39.6 \pm 2.9$ & $35.1 \pm 1.9$ & $35.1 \pm 1.9$ & $34.6 \pm 2.1$ \\
\hline T. albida & $46.3 \pm 2.2$ & $35.5 \pm 6.3$ & $33.9 \pm 33.9$ & $44.6 \pm 1.9$ & $40.0 \pm 3.1$ \\
\hline T.anceps & $65.9 \pm 2.9$ & $49.7 \pm 6.5$ & $50.3 \pm 1.2$ & $52.8 \pm 4.1$ & $54.7 \pm 3.7$ \\
\hline T. balbisiana & $59.8 \pm 1.1$ & $55.4 \pm 2.7$ & $44.1 \pm 3.5$ & $41.6 \pm 2.1$ & $50.2 \pm 2.3$ \\
\hline T. bourgaei & $34.3 \pm 2.1$ & $33.6 \pm 4.1$ & $28.3 \pm 2.7$ & $32 \pm 2.7$ & $32.0 \pm 2.9$ \\
\hline T. bulbosa & $35.4 \pm 2.0$ & $35.7 \pm 2.0$ & $60.6 \pm 4.9$ & $21.6 \pm 2.1$ & $38.3 \pm 2.7$ \\
\hline T. califani & $34.6 \pm 1.3$ & $27.7 \pm 2.8$ & $16.1 \pm 1.4$ & $12.8 \pm 1.9$ & $22.8 \pm 1.8$ \\
\hline T. caput-medusae & $54.3 \pm 2.7$ & $54.3 \pm 2.7$ & $16.1 \pm 1.1$ & $15.9 \pm 2.0$ & $35.1 \pm 2.1$ \\
\hline T. circinnatoides & $46.2 \pm 4.2$ & $54.1 \pm 1.3$ & $25.7 \pm 1.5$ & $28.6 \pm 2.8$ & $38.6 \pm 2.4$ \\
\hline T. crocata & $44.2 \pm 1.6$ & $57.7 \pm 2.5$ & $46.7 \pm 2.0$ & $57.7 \pm 2.5$ & $51.6 \pm 2.1$ \\
\hline T. cyanea & $58.1 \pm 2.6$ & $58.1 \pm 2.6$ & $35.7 \pm 1.7$ & $35.7 \pm 1.7$ & $46.9 \pm 2.1$ \\
\hline T. dasyliriifolia & $43.4 \pm 2.3$ & $33 \pm 2.8$ & $22.1 \pm 1.7$ & $19.8 \pm 1.0$ & $29.6 \pm 2.0$ \\
\hline T. duratii & $37.0 \pm 2.3$ & $38.6 \pm 0.5$ & $30.1 \pm 1.0$ & $31.2 \pm 2.8$ & $34.2 \pm 1.4$ \\
\hline T. fasciculata & $48.4 \pm 5.5$ & $60.2 \pm 4.0$ & $38 \pm 2.4$ & $39.6 \pm 2.9$ & $46.7 \pm 3.7$ \\
\hline T. flabellata & $30.2 \pm 1.3$ & $30.9 \pm 0.7$ & $24.7 \pm 1.4$ & $23.3 \pm 1.3$ & $27.3 \pm 1.2$ \\
\hline T. foliosa & $73.3 \pm 6.4$ & $65.3 \pm 2.3$ & $63.1 \pm 3.0$ & $55.6 \pm 2.7$ & $64.3 \pm 3.6$ \\
\hline T. grandis & $14.5 \pm 1.6$ & $11.2 \pm 1.2$ & $3.4 \pm 0.8$ & $3.3 \pm 0.7$ & $8.1 \pm 1.0$ \\
\hline T. grandis (juv.) & $27.4 \pm 3.6$ & $25.4 \pm 2.5$ & $5.3 \pm 1.1$ & $7.1 \pm 1.1$ & $16.3 \pm 2.8$ \\
\hline T. heterophylla & $26.4 \pm 2.1$ & $26.4 \pm 2.1$ & $20.6 \pm 1.4$ & $20.6 \pm 1.4$ & $23.5 \pm 1.7$ \\
\hline T. ionantha & $33.7 \pm 2.2$ & $25.3 \pm 2.6$ & $15.8 \pm 1.5$ & $14.3 \pm 1.2$ & $22.3 \pm 1.8$ \\
\hline T. juncea & $58.6 \pm 5.2$ & $43.9 \pm 1.4$ & $46.7 \pm 2.9$ & $46.7 \pm 2.9$ & $49.0 \pm 3.1$ \\
\hline T. karwinschyana & $39.1 \pm 1.5$ & $35.9 \pm 1.1$ & $27.8 \pm 2.5$ & $27.8 \pm 2.5$ & $32.6 \pm 1.9$ \\
\hline T. latifolia & $32.2 \pm 1.5$ & $30 \pm 1.6$ & $17.7 \pm 1.2$ & $16.5 \pm 0.9$ & $24.1 \pm 1.3$ \\
\hline T. paleacea & $36.1 \pm 1.6$ & $32.9 \pm 3.1$ & $33 \pm 1.5$ & $32.2 \pm 1.1$ & $33.5 \pm 1.8$ \\
\hline T. prodigiosa & $18.5 \pm 1.2$ & $15.3 \pm 1.6$ & $24.6 \pm 1.6$ & $23.2 \pm 2.0$ & $20.4 \pm 1.6$ \\
\hline T. punctulata & $52 \pm 1.7$ & $45 \pm 2.1$ & $39.3 \pm 1.5$ & $46.3 \pm 1.4$ & $45.6 \pm 1.7$ \\
\hline T. purpurea & $26.7 \pm 1.9$ & $13.3 \pm 0.9$ & $28.7 \pm 2.0$ & $25.7 \pm 0.8$ & $23.6 \pm 1.4$ \\
\hline T. recurvata & $29 \pm 1.9$ & $29 \pm 1.9$ & $30 \pm 1.7$ & $30 \pm 1.7$ & $29.5 \pm 1.8$ \\
\hline T. remota & $51.6 \pm 2.3$ & $51.6 \pm 2.3$ & $56 \pm 1.6$ & $56 \pm 1.6$ & $53.8 \pm 1.9$ \\
\hline T. schiedeana & $46.1 \pm 3.0$ & $50.6 \pm 3.4$ & $40.5 \pm 1.7$ & $45.9 \pm 1.2$ & $45.8 \pm 2.3$ \\
\hline T. seleriana & $32 \pm 2.6$ & $34.9 \pm 1.6$ & $10.5 \pm 2.1$ & $10.5 \pm 2.1$ & $22.0 \pm 2.1$ \\
\hline T. tectorum & $43.5 \pm 2.5$ & $43.5 \pm 2.5$ & $40 \pm 2.1$ & $40 \pm 2.1$ & $41.7 \pm 2.3$ \\
\hline T. tricolor & $54.7 \pm 2.2$ & $53.2 \pm 5.8$ & $44.2 \pm 3.2$ & $44.2 \pm 2.2$ & $49.1 \pm 3.6$ \\
\hline T. usneoides & $24.5 \pm 3.1$ & $24.4 \pm 3.1$ & $24.5 \pm 3.1$ & $24.5 \pm 3.1$ & $24.5 \pm 3.1$ \\
\hline T. violacea & $18.9 \pm 1.5$ & $19.5 \pm 2.6$ & $34.3 \pm 1.5$ & $26.9 \pm 3.3$ & $24.9 \pm 2.2$ \\
\hline T. xerographica & $48 \pm 1.6$ & $45 \pm 2.5$ & $42.2 \pm 4.4$ & $41.5 \pm 2.5$ & $44.2 \pm 2.7$ \\
\hline
\end{tabular}

ADPRO $=$ Adaxial Proximal ADDIS $=$ Adaxial Distal ABPRO $=$ Abaxial Proximal; ABDIS $=$ Abaxial Distal. Values are indicated $+/$ - Standard deviation. 
TABLE 3

T number values with standard deviation for each investigated species

T Number with standard deviation

\section{T. achyrostachys}

$0.68 \pm 0.01$

T. albertiana

$0.97 \pm 0.1$

T. albida

$2.60 \pm 0.2$

T.anceps

$1.53 \pm 0.1$

T. balbisiana

$2.41 \pm 0.1$

T. bourgaei

$2.53 \pm 0.2$

T. bulbosa

$2.42 \pm 0.2$

T. califani

$1.44 \pm 0.1$

T. caput-medusae

$3.47 \pm 0.2$

T. circinnatoides

$2.42 \pm 0.1$

$5.84 \pm 0.3$

$0.70 \pm 0.03$

T. cyanea

$1.39 \pm 0.1$

$3.39 \pm 0.1$

$2.85 \pm 0.2$

$0.49 \pm 0.02$

$1.37 \pm 0.05$

$0.15 \pm 0.02$

$1.37 \pm 0.2$

$0.094 \pm 0.0$

$2.01 \pm 0.1$

$3.28 \pm 0.2$

$4.73 \pm 0.3$

$1.59 \pm 0.1$

$3.15 \pm 0.2$

$0.79 \pm 0.1$

$1.23 \pm 0.05$

$3.07 \pm 0.2$

$3.57 \pm 0.2$

$2.26 \pm 0.1$

$4.03 \pm 0.2$

$1.85 \pm 0.2$

$9.88 \pm 0.5$

$1.32 \pm 0.1$

$2.35 \pm 0.3$

$0.82 \pm 0.1$

$1.81 \pm 0.1$

\section{DISCUSSION}

Considering the analysis of the general data and the T numbers, we were able to propose five ecological types.

In order to clarify the meaning of number $\mathrm{T}$, we can say, for instance, that a species $\mathrm{x}$ with a $\mathrm{T}$ number $=1$ owns on average, for each $\mathrm{mm}^{2}$ of leaf surface, another $\mathrm{mm}^{2}$ of surface deriving from the aerial part of trichomes. In the same way a species y with $\mathrm{T}=0.5$ owns for each $\mathrm{mm}^{2}$ of leaf surface still $0.5 \mathrm{~mm}^{2}$ of plus surface due to trichomes. Finally a species $\mathrm{z}$ with $\mathrm{T}=2$ would have, for each $\mathrm{mm}^{2}$ of epidermis surface, other $2 \mathrm{~mm}^{2}$ of exposed surface.

The identification of ecological types is linked to the possibility of finding coherent and discrete intervals in the numerical sequence of Tab. 3, where each number corresponds to the value of surface increase due to trichomes in a given taxon.

The analysis leads to the identification of five ecological types, each grouping a sequence of numbers. They are: the minimally expanded $(\mathrm{T}<1)$, the poorly expanded $(1 \leq \mathrm{T}<2)$, the averagely expanded $(2 \leq \mathrm{T}<3)$, the highly expanded $(3 \leq \mathrm{T}<4)$ and the utmostly expanded $(\mathrm{T} \geq 4)$.

A factor confirming the validity of these groups of species is the good correspondence between a given ecological type and a specific habitat. The species with very low $\mathrm{T}(<1)$ are almost always Tillands of habitats where water and organic material availability through leaching is high for the plants. Of course in such situations a high trichomes number is superfluous and so an expanded trichome wing. On the contrary, species characterized by very high $\mathrm{T}$ values $(>4)$ are plants living in arid and windy environments, with poor organic supplies, or plants preferring ecological niches more exposed to sun radiation and hence less defended from atmospherical dynamics (tree crowns, deserts, high tension wires, cables and so on).

Analyzing more in detail the ecological types here proposed, we find the following results. 


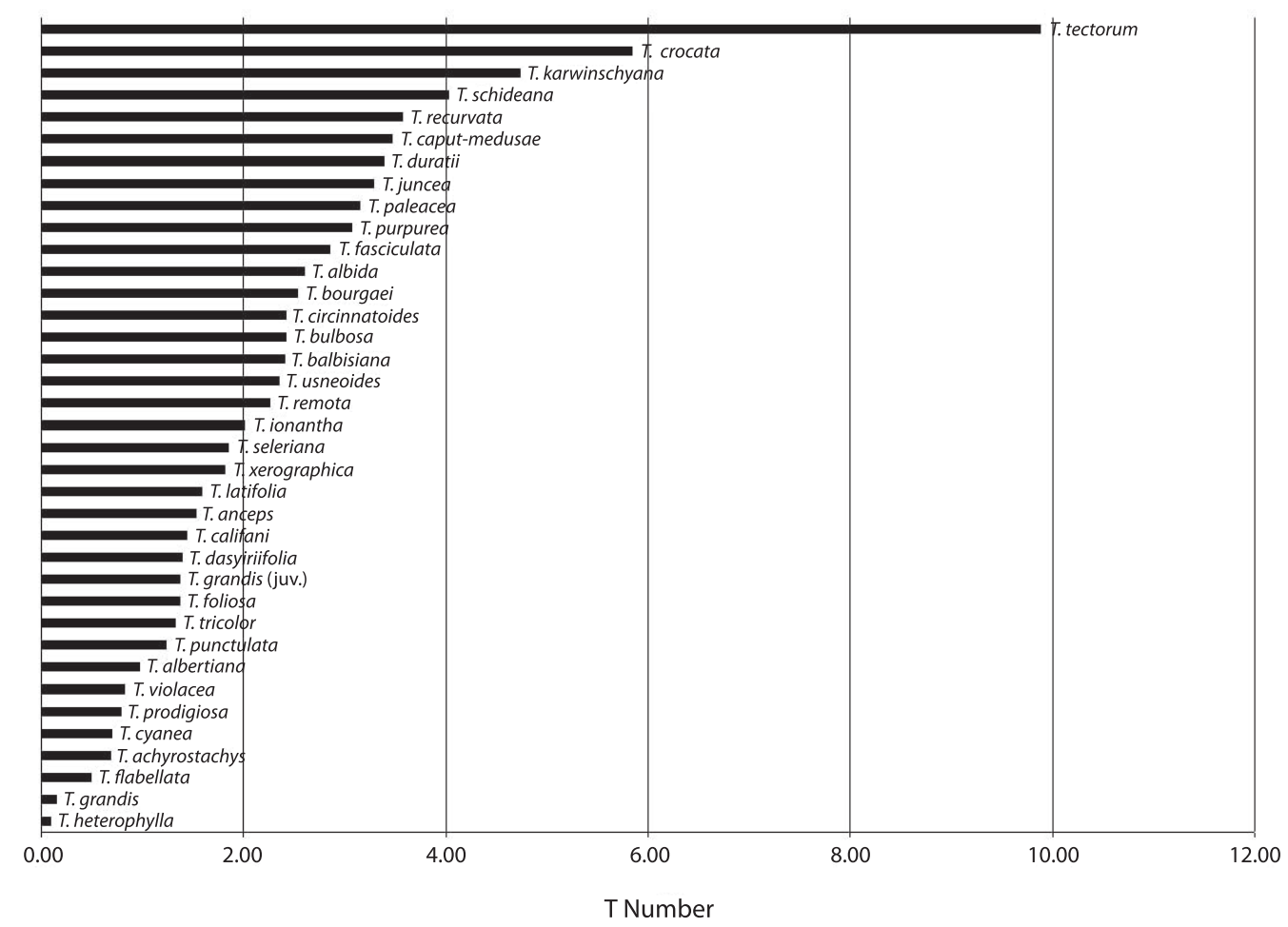

Fig. 7. T values in ascending order.

Species with $T<1$ belong to the ecological type of the minimally expanded. Species as T. heterophylla, T. violacea and T. cyanea are plants adapted to humid or very humid environments as rain forests or tropical forests. On the contrary $T$. grandis is a large dimensions species (relatively to the average dimensions of the representatives of this genus), often saxicolous, able to colonize also more exposed habitats and hence more subjected to evaporation. This species can counterbalance the weak surface increase with a high tank capacity. In $T$. grandis, characterized by noteworthy dimorphism between the young and the adult plants, we examined the trichomes of both forms separatedly. As it happens in T. deppeana, also this taxon shows an evident simplification and reduction in frequency and dimension of the absorbing trichomes passing from the "neotenic" (young) form to the adult form (Adams e Martin 1986), probably counterbalanced by the growth in dimension of the plant and hence the increased capability to intercept and retain water and solutes inside the rosetta leaves. In fact the young specimens of $T$. grandis showed to belong to the following ecological type (Poorly expanded).

The poorly expanded type is characterized by a number $1 \leq \mathrm{T}<2$. Species of wet habitats belong also to this type, as T. punctulata and T. tricolor, but also species as T. califani or $T$. dasyliriifolia, living in habitays characterized by periods of lower intensity rain, but with a high tank capacity, such to counterbalance an apparently too low surface increase by trichomes. Moreover this species or other as $T$. xerographica can take advantage by a further exposed surface increase due to microconcavities on the walls of the trichome wing (Mosti et al. 2005).

The averagely expanded type includes species with $2 \leq \mathrm{T}<3$. This group comprises dry 
habitat species (e. g. T. albida), but also species of intermediate environments or widely distributed (e. g. T. fasciculata). Often species belonging to this type reach lower average dimension (e. g. T. ionantha, T. crocata) with respect to those of the previous type. Hence the higher covering of trichomes would counterbalance the lower capability of the plant, considered as a whole, to capt water and nutrients.

The highly expanded type, that is with $3 \leq \mathrm{T}<4$ includes dry habitats species $(T$. recurvata), other subjected to high water loss as coastal species (T. purpurea, T. paleacea) or however living in habitats with high direct sunlight ( $T$. duratii). Also species that can live in intermediate environments (T. juncea, $T$. caput-medusae) belong to this group. This last two cases concern species of little dimension: the first with a very thin foliar lamina and very reduced tank, and the second mirmecophytic, with a bulbous (tankless) habitus. The above remembered features justify the necessity of higher surface increase with respect to what we could expect considering only the growth environment.

The last type is the utmostly expanded with $\mathrm{T} \geq 4$. The $\mathrm{T}$ coefficient is particularly high in T. tectorum $(\mathrm{T}=9.88)$, much higher than in the other species of this group. Anyway we didn't consider useful to create a group expressly for this only species. The species of this group (also of arid environments or somehow highly exposed to direct sunlight) are often of smaller dimension and tankless with respect to those of the previous group. In general we can say that the species belonging to this group are characterized by a quite high number of trichomes/ $\mathrm{mm}^{2}$ and very large trichome wings (almost in any case $>0.1 \mathrm{~mm}^{2}$ ).

The first, the second and part of the third of our ecological types fitted quite well with Pittendrigh's (1948) Type Three ('tank absorptive trichome') and to Benzing's (2000) Type IV; while our last two types fitted with Pittendrigh's (1948) Type Four ('atmospheric, absorptive trichome') and to Benzing's (2000) Type V.

TABLE 4

Subdivision in ecological types on the basis of the increase in value of $T$

(enhancement of leaf surface due to the number of scales $/ \mathrm{mm}^{2}$ and to the wing dimension of the scale)

Minimally expanded species $(\mathrm{T}<1)$

T. heterophylla Morren

T. grandis (fully-grown) Schlecht

T. flabellata Baker

T. achyrostachys Morren

T. cyanea Linden

T. prodigiosa (Lem.) Baker

T. violacea (Beer) Baker

T. foliosa Martens et Galeotti

T. albertiana $\mathrm{F}$. Vervoorst

Poorly expanded species $(1 \leq \mathrm{T}<2)$

T. punctulata Schlect et Chram.

T. tricolor Schlecht. et Cham.

$T$. grandis (youth) Schlecht.

T. dasyliriifolia Baker

T. califani Rauh

T. anceps Lodd.

T. latifolia Meyen

T. xerographica Rawh.

T. seleriana $\mathrm{Mez}$

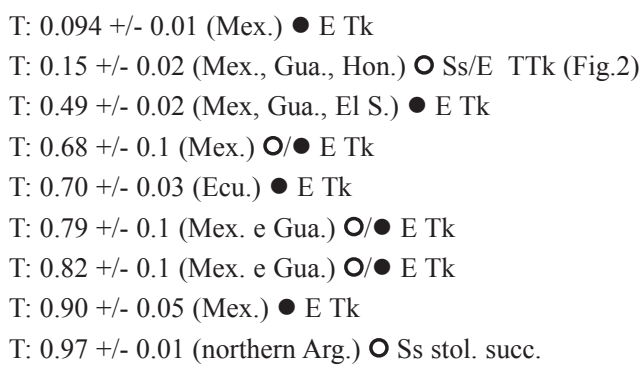

T: $1.23+/-0.05$ (Mex. to Per.) O tk E

T: $1.32+/-0.1(+\mathrm{m})$ (Mex., Gua., C. Ric., Nic.) O E Tk

T: $1.37+/-0.2$ (Mex., Gua., Hon.) O E/Ss TTk

T: $1.39+/-0.1(+\mathrm{m})$ (Mex. to Col.) O E Tk

T: $1.44+/-0.1$ (central Mex.) $\bigcirc \mathrm{E} \mathrm{Tk}$

T: $1.53+/-0.1(+\mathrm{m})$ (central Amer., Trin., south Amer.) O/๑ E

T: $1.59+/-0.1$ (Col., Ecu., Per.) $\bigcirc \mathrm{Ss} \approx$ tk stol.

T: $1.81+/-0.1(+\mathrm{m})$ (El. S., Gua., Mex.) O/O E tk

T: $1.85+/-0.2$ (Mex. to Hon.) O/O E b succ. (Fig. 3) 
TABLE 4 (Continued)

Subdivision in ecological types on the basis of the increase in value of $T$

(enhancement of leaf surface due to the number of scales $/ \mathrm{mm}^{2}$ and to the wing dimension of the scale)

Averagely expanded species $(2 \leq \mathrm{T}<3)$

T. ionantha Planch

T. bulbosa Hook.

T. remota Wittm.

T. usneoides (L.) L

T. balbisiana Schult.

T. crocata (Morren) Baker

T. bourgaei Baker

T. albida Mez et Purp.

T. fasciculata SW.

Highly expanded species $(3 \leq \mathrm{T}<4)$

T. purpurea Ruiz et Pav.

T. paleacea Presl

T. juncea (R. \& P.) Poir.

$T$ duratii Vis.

T caput-medusae Mor.

T. recurvata (L.) L

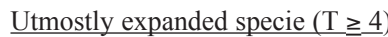

T. schiedeana Steud.

T. karwinskyana Schult fil.

T. circinnatoides Matuda

T. tectorum Morren

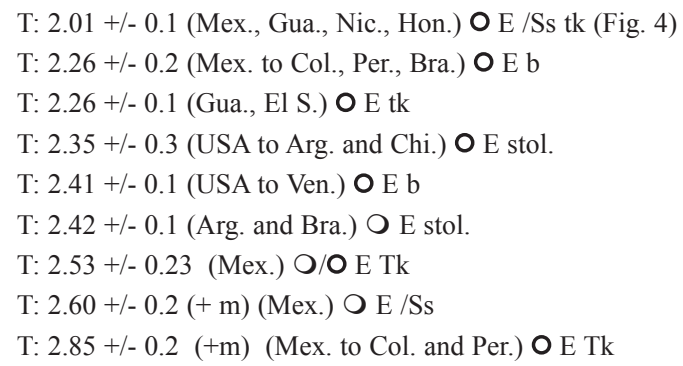

T: $3.07+/-0.2$ (Per.) $\bigcirc \approx$ Ss stol. (Fig. 5)

T: $3.15+/-0.2$ (Col., Per., Bol., Chil.) $\bigcirc \approx$ Ss stol.

T: $3.28+/-0.2$ (central Amer. to Bol. and Per.) O/O E tk

T: $3.39+/-0.1$ (Arg., Uru. and Bol.) O/O E

T: 3.47 +/- 0.2 (Mex.,Gua.,El S.,Hon.,C. Ric.) O/O E b

T: $3.57+/-0.2 \bigcirc$ (southern USA to Arg. and Chi.) $\bigcirc \mathrm{E} / \mathrm{Ss}$ stol.
Symbols legend

O: Environments completely exposed to direct sun light

O: Environments of average exposure to direct sun light

-:Environments poorly exposed to direct sun light

b: bulbous species

stol.: stoloniferous species

succ.: succulent species

$\approx$ : sea shores environment species

E: epiphytic species

Ss: saxicolous species (terrestrial)

At last, in Table 4 the species, subdivided into five ecological types, are related to their morphological and ecological features and to their environmental and geographical distribution. It allows comparison of the calculated surface increase (indicated by $\mathrm{T}$ number) and the ecological niche and morphology the species. The capability of some species to gain a wide range could depend on a particular wing dimension and frequency of trichomes. tk: poor tank capacity

Tk,: high tank capacity

TTk: very high tank capacity

$(+\mathrm{m})$ : further increase due to microconcavities in the walls of the wing cells

Amer.: America; Arg.: Argentina; Bol.: Bolivia; Bra.: Brazil; Chi.: Chile; Col.: Colombia; C. Ric.: Costa Rica; Ecu.: Ecuador; El. S.: El Salvador; Gua.: Guatemala; Hon.: Honduras; Mex.: Mexico; Nic.: Nicaragua; Per.: Peru; Trin.: Trinidad; Uru.: Uruguay; Ven.: Venezuela.

Few species of the most extreme environments show a lower $\mathrm{T}$ value than expected (for example: T. grandis, T. albertiana, T. dasyliriifolia, T. califani, T. xerographica, T. latifolia). Factors that may explain this are: leaf succulence ( $T$. albertiana), a developed tank and hence the capability to entrap water and debris (T. grandis, T. dasyliriifolia, T. califani, T. latifolia), and the presence of microcavities in the walls of the wing cells (T. dasyliriifolia, 
T. xerographica). These morphological features must not be evaluated as discriminating elements for an ecological classification, but as factors that explain an unexpected position of the species along the scale.

On the contrary, some bulbous mirmecophytes (T. bulbosa, T. caput-medusae, T. seleriana) show a high $\mathrm{T}$ value considering their environment. The reason is linked to the fact that, in these cases, a high increse in leaf surface is useful for the plant in order to provide adequate sites for its associated ants. Some Tillands, such as T. califani, that occur in arid environments but have a very low $\mathrm{T}$ value (without any other observable feature useful to counterbalance this disadvantage), can be considered species of little success. On the contrary, other species such as $T$. fasciculata (which also shows a further increase in leaf surface due to microcavities, a factor of difficult evaluation) have high $\mathrm{T}$ values considering their environments. They are successful in their areal distribution, with many infraspecific entities capable of living in ecological niches with very different climatic situation (Smith and Downs 1977).

Aware of the difficulties of the present attempt to propose for genus Tillandsia new ecological types based on trichomes, we remark that, in spite of what is available in the literature (Pittendrig 1948, Gilmartin 1973, Benzing 2000), we go beyond the affinity of the habitus defining our five types on the basis of experimental numerical data that can be objectively reproduced.

We think that further studies, extended to the many species of Tillandsia not covered by this investigation, will verify the efficiency of the methodology applied here.

\section{RESUMEN}

Medimos el número por milímetro cuadrado y el área del "ala" (parte móvil) de los tricomas en las partes adaxial próxima y distal, y adaxial próxima y distal, de la hoja de 37 especies de bromelias del género Tillandsia. El producto del área del ala para el número de los tricomas (promedio) produjo un número puro $(\mathrm{T})$. Hallamos que $\mathrm{T}$ se correlaciona con las características ecológicas de las tilandsias investigadas. La correlación es positiva con respecto a ambientes áridos (especies xéricas) y negativa con respecto a los ambientes húmedos (especies mésicas). Las especies con bulbo, y particularmente las asociadas con hormigas y especies con de tanque representan categorías particulares. Identificamos otros tipos intermedios, agradando así cinco tipos ecológicos. En comparación con otros sistemas de tipificación ecológica, este sistema ofrece la ventaja de ser reproducible y cuantitativo.

Palabras claves: Bromeliaceae, tipos ecológicos, Tillandsia, tricoma.

\section{REFERENCES}

Adams W.W. \& C.E. Martin. 1986. Morphological changes accompaning the transition from juvenile (atmospheric) to adult (tank) forms in the mexican epiphyte Tillandsia deppeana (Bromeliaceae). Amer. J. Bot. 73: 1207-1214.

Benzing D.H. \& A. Renfrow. 1971. The significance of photosynthetic efficiency to habitat preference and phylogeny among tillandsioid bromeliads. Bot. Gaz. 132: $19-30$

Benzing D.H. 1979. Alternative interpretations for the evidence that certain orchids and bromeliads act as shot parasites. Selbyana 5: 135-144

Benzing, D.H. 1980. The Biology of Bromeliads. Mad River, Eureka, California, U.S.A.

Benzing, D.H. 2000. Bromeliaceae: profile of an adaptive radiation. Cambridge University, Cambridge, England.

Benzing, D.H., J. Seeman, and A. Renfrow. 1978. The foliar epidermis in Tillandsioideae (Bromeliaceae) and its role in habitat selection. Am. J. Bot. 65: 359-365.

Billings, F.H. 1904. A study of Tillandsia usneoides. Bot. Gaz. 38: 99-121

Brighigna, L. 1991. Essential aspects of the Epiphytic Strategy of Tillandsia (Bromeliaceae). Atti Primo Contributo dell'Università di Firenze allo studio delle realtà ambientali dell'America Latina, Firenze, 11 ottobre 1991: 21-33.

Brighigna, L., M.R. Palandri, M. Giuffrida, C. Macchi \& G. Tani. 1988. Ultrastructural features of the Tillandsia 
usneoides L. absorbing tricome during conditions moisture and aridity. Caryologia 41: 111-129.

Brighigna, L., P. Montaini, F. Favilli, \& A.C. Trejo. 1992. Role of the Nitrogen-Fixing Bacterial Microflora in the epiphytism of Tillandsia (Bromeliaceae). Amer. J. Bot. 79: 723-727.

Favilli, F., S. Caroppo, L. Brighigna. 1975. Batteri azotofissatori associati a Tillandsia spp.. Atti XVII Congr. Nazionale Società Ital. Microbiologia. Padova, Italy.

Foster, S.A. 1950. Morphology and venation of the leaf in Quina acutangula Ducke. Amer. J. Bot. 37: 159-171.

Gilmartin, A.J. 1973. Transandean distributions of Bromeliaceae in Ecuador. Ecology 54: 1389-1393.

Gilmartin, A.J. 1983. Evolution of Mesic and Xeric Habits in Tillandsia and Vriesea (Bromeliaceae). Systematic Bot. 8: 233-242.

Mez, C. 1904. Physiologische Bromeliaceen-Studien. I. Die Wasser-Oekonomie der extrem atmosphärischen Tillandsien. Jahrb. wissen. Bot. 40: 157-229.

Mez, C. 1935. Bromeliaceae. In Engler A., Planzenreich 100 (IV, 32). S.D.

Mosti, S., M. Raffaelli \& L. Brighigna. 2005. The Tillandsia L. trichome and its use in species identification. Webbia 60: 577-598.
Pittendrigh, C.S. 1948. The bromeliad-Anopheles-malaria complex in Trinidad. I. The bromeliad flora. Evolution 2: 58-89.

Rauh, W. 1981. Bromelien - Tillandsien und andere kulturwürdige Bromelien. Eugen, Ulmer, Stuttgart, Germany.

Smith, L.B. \& R.J. Downs. 1977. Tillandsioideae. In Flora Neotropica 14 (2). Hafner, New York, U.S.A.

Strehl, V.T. \& S. Winkler. 1981. Vergleichende Untersuchungen über die Trichome der Bromeliaceen. Beitr. Biol. Pflanzen 56: 415-438.

Tomlinson, P.B. 1969. Anatomy of the monocotyledons: III. Commelines-Zingiberales. Oxford, Oxford, England.

Tukey, H.B. Jr. 1970. The leaching of substances from plants. Annu. Rev. Plant Physiol. 21: 305-324.

Winkler, S. 1980. Ursachen der Verbreitungsmuster einiger Bromeliaceae in Rio Grande do Sul (Südbrasilien). Flora 170: 371-393.

Winkler, S. 1986. Differenzierung und deren Ursachen innerhalb der Bromeliaceen. Beitr. Biol. Pflanzen 61: 283-314.

Winkler, S. 1990. Zur Evolution der Gattung Tillandsia L. Bot. Jahrb. Syst. 112: 43-77. 
